\title{
VAARAMOREENIN LANNOITUS- JA KALKITUSKOKEEN TULOKSIA
}

\author{
HEIKKI LUOSTARINEN \\ Suoviljelysyhdistys, Karjalan koeasema, Tohmajärvi
}

Saapunut 6. 3. 1967

Itä-Suomelle tyypillisten vaaramaiden lannoituksen ja kalkituksen tarpeen selvittämiseksi on Suoviljelysyhdistyksen toimesta Tohmajärven Kemienvaaralle perustettu pitkäaikainen kenttäkoe vuonna 1944. Sen tuloksia on alustavasti selostanut SALOHEImo (1951, 1958). Koealueen maaperän rakennetta ja samalla vaaramoreenin ominaisuuksia kuvastaa maaperäleikkaus Kemienvaarasta Tohmajärveltä KrvisEN (1941) mukaan:

$0-28 \mathrm{~cm}$, multakerros

$28-33 \mathrm{~cm}, \mathrm{~A}_{2}$, uuttunut, aivan valkoinen kerros, $\mathrm{pH} 5.76$

$33-61 \mathrm{~cm}, \mathrm{~B}$, keltaisen ruskea moreenihieta, $\mathrm{pH} 5.59$

$61-77 \mathrm{~cm}, \mathrm{C}$, ruskea moreenihieta, $\mathrm{pH} 6.13$

77- cm, ruskea, kova pohjamoreeni
Löyhä

pinta-

moreeni

\section{Koesuunnitelma ja -tulosten kästttelytapa}

Selostettavassa kokeessa tutkittiin väkilannoitteissa annetun typen, fosforin ja kalin vaikutusta satoon ilman kalkitusta sekä kalkkia ja karjanlantaa käyttäen. Koejäsenet olivat seuraavat:

A. Koejäsenryhmä ilman kalkkia ja karjanlantaa. Lannoitukset: (1), N, P, K, NP, $\mathrm{NK}, \mathrm{NPK}$ ja PK. N $=15 \mathrm{~kg} /$ ha $\mathrm{N}$ kalkkisalpietarina, $\mathrm{P}=21.9 \mathrm{~kg} / \mathrm{ha} \mathrm{P}$ superfosfaattina ja $\mathrm{K}=66.4 \mathrm{~kg} / \mathrm{ha} \mathrm{K}$ kalisuolana vuosittain.

B. Koejäsenryhmä, jossa on annettu kalkkikivijauhetta 2 t/ha pintalevityksenä nurmelle kokeen perustamisvuonna 1944 ja toisen kerran sama kalkkimäärä vuonna 1951. Lannoitukset kuten koejäsenryhmässä A.

C. Koejäsenryhmä, joka on otettu kokeeseen vuonna 1949. Karjanlantalannoitus 40 t/ha, mikä toistettiin vuonna 1962. Lannoitukset kuten koejäsenryhmässä A. 
Koejäsenryhmät sijoitettiin kolmelle vierekkäiselle kaistalle. Kaistan koko oli $16.5 \times 106 \mathrm{~m}$. Lannoitusjäsenistä oli neljä kerrannetta jokaisessa koejäsenryhmässä. Lannoitusruudun koko oli $50 \mathrm{~m}^{2}$. Kokeen tulokset on esitetty kahden ensimmäisen koejäsenryhmän osalta väkilannoitus- kalkituskokeen nimellä ja kaikkien koejäsenryhmien osalta karjanlantakokeen nimellä.

Kokeen kasvijärjestys oli seuraava:

$\begin{array}{llll}\text { Vuosi } & \text { Koekasvi } & \text { Vuosi } & \text { Koekasvi } \\ 1944 & \text { Heinä } & 1955 & \text { Heinä } \\ 1945 & & 1956 & \\ 1946 & & 1957 & \\ 1947 & \text { Syysruis } & 1958 & \text { Syysruis } \\ 1948 & \text { Hernekaura } & 1959 & \text { Kevätvehnä } \\ 1949 & \text { Ohra } & 1960 & \text { Kevätruis } \\ 1950 & \text { Heinä } & 1961 & \text { Kesanto } \\ 1951 & , & 1962 & \text { Syysruis (ei koetulok- } \\ 1952 & \text { Syysruis } & 1963 & \text { Kevätvehnä } \\ 1953 & \text { Ohra } & 1964 & \text { sia) }\end{array}$

Eri vuosien (kasvien), lannoitusten ja koejäsenryhmien välistä vaihtelua sekä mainittujen tekijöiden yhteisvaikutuksia on selvitelty varianssianalyysillä (vrt. BONNIER ja TEDIN 1957). Ravinteiden pää- ja yhteisvaikutukset on laskettu jokai-

Taulukko 1. Lannoitusten ja kalkituksen vaikutus kevätviljojen jyväsatoihin, $\mathrm{kg} / \mathrm{ha}$ (5 vuotta). Table 1. The effect of fertilizations and liming on the grain yields of spring cereals, $\mathrm{kg}$ per ha (5 years).

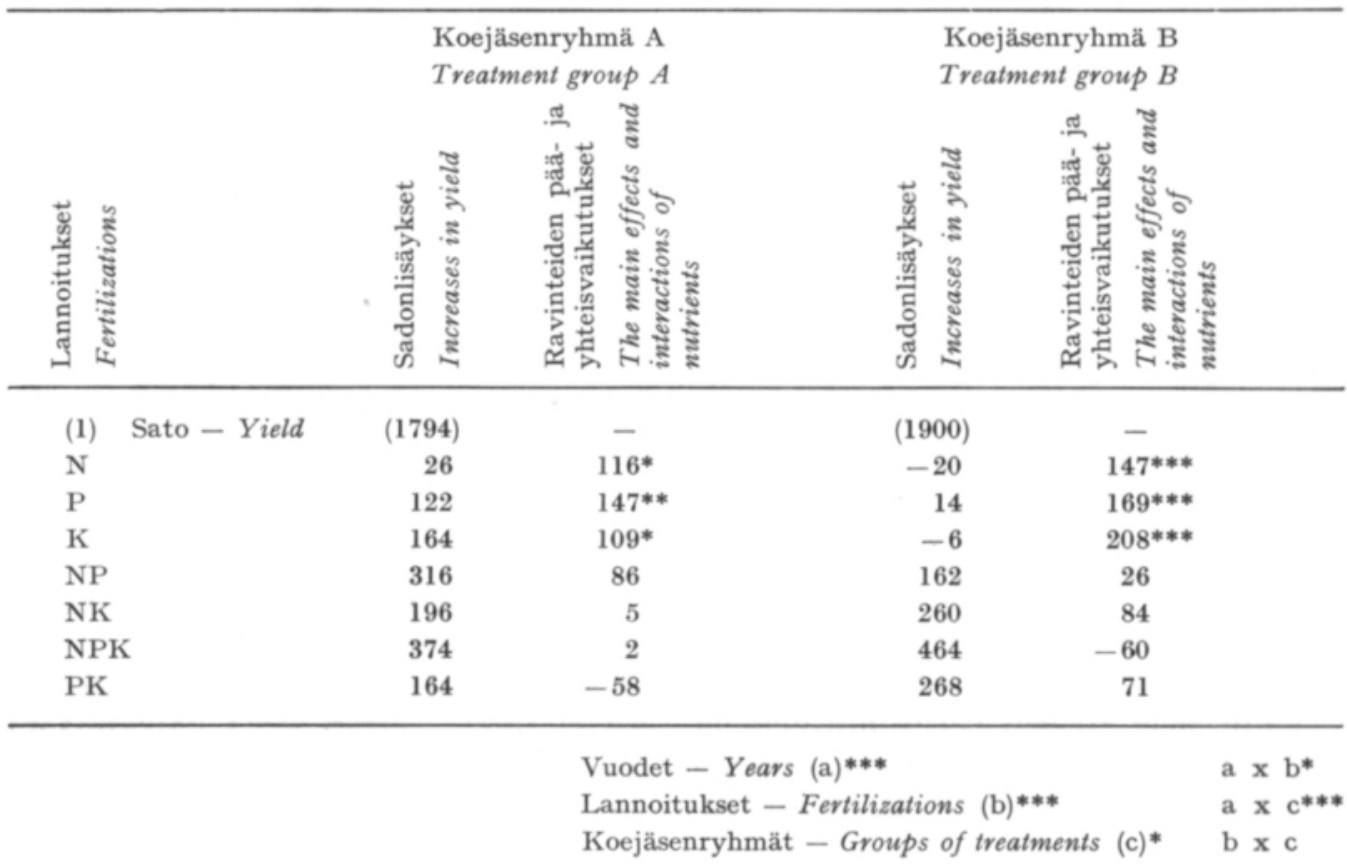


selta koejäsenryhmältä erikseen ja niiden merkitsevyydet on testattu jakamalla lannoitusten välinen neliösumma eri komponentteihin (BAILEY 1964). Ravinteiden pää- ja yhteisvaikutusluvut on esitetty neljäsosana ortogonaalisten vertailujen arvosta. Ravinteiden osuudet NPK-lannoituksella saadusta sadonlisäyksestä on laskettu siten, että NPK-yhteisvaikutus on jaettu tasan eri päävaikutuksille (menetelmä I). Ravinteiden vaikutukset on laskettu myös parittaisista lannoiteyhdistelmistä (vrt. TENNBERG 1939) jakamalla sekundäärinen yhdistelmävaikutus tasan eri ravinteille (menetelmä II).

\section{Väkilannoitus-kalkituskokeen tulokset}

Koetuloksia on tarkasteltu erikseen kevätviljojen, rukiin ja heinän osalta. Kaikkien kevätviljojen tulokset esitetään keskimääräisinä, sillä koevuosia on liian vähän eri kasvien erittelyyn. Kevätvehnässä ilmenneet tyvitaudit (Ophiobolus graminis ja Cereosporella herpotrichoides) vaikuttivat vuonna 1965 jyväsatoihin siinä määrin, että nämä tulokset on otettu vain kaikkien kasvien keskimääräisiin koetuloksiin, joissa myös olkisadot ovat mukana. Kevätviljojen keskimääräiset jyväsadot on laskettu viiden vuoden koetuloksista (taulukko 1). Satotaso on vaihdellut vuosittain voimakkaasti. Lannoitusjäsenten välillä on todettavissa erittäin merkitseviä eroja $(\mathrm{P}<0.001)$. Kalkitus on lisännyt satoja merkitsevästi $(\mathrm{P}<0.05)$, mutta kalkituksen vaikutus on eri vuosina (eri kevätviljoilla) vaihdellut voimak-

Taulukko 2. Eri ravinteiden keskimääräinen vaikutus kevätviljojen jyväsatoihin, $\mathrm{kg} / \mathrm{ha}$ ja $\mathrm{kg} / \mathrm{ravinne}$ $\mathrm{kg}$ (5 vuotta).

Table 2. Average effect of different nutrients on the grain yields of spring cereals, $\mathrm{kg}$ per ha and $\mathrm{kg}$ per $\mathrm{kg}$ nutrient (5 years).

\begin{tabular}{|c|c|c|c|c|c|c|c|c|}
\hline \multirow{3}{*}{$\begin{array}{c}\text { Koejäsenryhmät } \\
\text { Groups of } \\
\text { treatments }\end{array}$} & \multirow{3}{*}{$\begin{array}{c}\text { Menetelmä } \\
\text { Method }\end{array}$} & \multicolumn{2}{|c|}{$\mathrm{N}$} & \multicolumn{2}{|c|}{$\mathbf{P}$} & \multicolumn{2}{|c|}{$\mathbf{K}$} & \multirow[t]{2}{*}{ NPK } \\
\hline & & \multicolumn{6}{|c|}{ Sadonlisäykset - Increases in yield } & \\
\hline & & $\mathrm{kg} / \mathrm{ha}$ & $\mathrm{kg} / \mathrm{kgN}$ & $\mathrm{kg} / \mathrm{ha}$ & $\mathrm{kg} / \mathrm{kgP}$ & $\mathrm{kg} / \mathrm{ha}$ & $\mathrm{kg} / \mathrm{kgK}$ & $\mathrm{kg} / \mathrm{ha}$ \\
\hline \multirow[t]{2}{*}{ A } & I & 117 & 7.8 & 147 & 6.7 & 110 & 1.7 & 374 \\
\hline & II & 186 & 12.4 & 154 & 7.0 & 34 & 0.5 & 374 \\
\hline \multirow[t]{2}{*}{ B } & I & 127 & 8.5 & 149 & 6.8 & 188 & 2.8 & 464 \\
\hline & II & 117 & 7.8 & 125 & 5.7 & 222 & 3.3 & 464 \\
\hline
\end{tabular}

kaasti. Kalin vaikutus on ollut kalkkia käytettäessä parempi kuin ilman kalkitusta, mikä näkyy myös eri ravinteilla saaduista sadonlisäyksistä (taulukko 2).

Syysruis on ollut koekasvina kolme kertaa ja kevätruis kerran. Kalkituksen vaikutus käytettäessä täyslannoitusta on ollut yhtä hyvä kuin kevätviljoilla (taulukko 3). Lannoitusten ja kalkituksen tehot vaihtelevat vuosittain voimakkaasti kuten varianssianalyysi ja taulukko 4 osoittavat. Fosforilannoituksen vaikutus 
Taulukko 3. Lannoitusten ja kalkituksen vaikutus rukiin jyväsatoihin, $\mathrm{kg} / \mathrm{ha}$ (4 vuotta).

Table 3. The effect of fertilizations and liming on the grain yields of rye, $\mathrm{kg}$ per ha (4 years).

\begin{tabular}{|c|c|c|c|c|}
\hline \multirow[b]{2}{*}{ 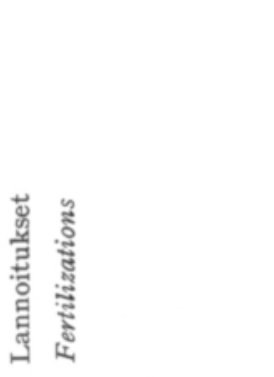 } & \multicolumn{2}{|c|}{$\begin{array}{l}\text { Koejäsenryhmä } \mathrm{A} \\
\text { Treatment group } A\end{array}$} & \multicolumn{2}{|c|}{$\begin{array}{l}\text { Koejäsenryhmä } \mathrm{B} \\
\text { Treatment group } B\end{array}$} \\
\hline & 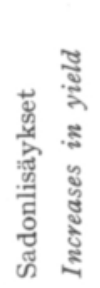 & 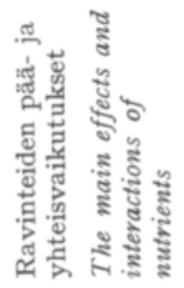 & 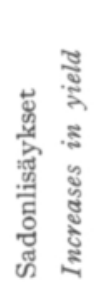 & 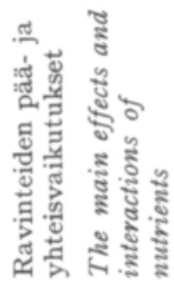 \\
\hline (1) Sato - Yield & (1548) & - & (1535) & - \\
\hline $\mathrm{N}$ & -190 & 57 & 143 & 43 \\
\hline $\mathbf{P}$ & 142 & $319^{* * *}$ & 263 & $366^{* * *}$ \\
\hline $\mathrm{K}$ & -41 & 39 & 98 & $184^{*}$ \\
\hline NP & 347 & 147 & 352 & 86 \\
\hline NK & -31 & 49 & 152 & 69 \\
\hline NPK & 364 & -51 & 563 & -30 \\
\hline PK & 162 & -21 & 395 & -12 \\
\hline
\end{tabular}

$\begin{array}{ll}\text { Vuodet }- \text { Years (a)*** } & \mathrm{a} \times \mathrm{b}^{* * *} \\ \text { Lannoitukset }- \text { Fertilizations (b)*** } & \mathrm{a} \times \mathrm{c}^{* * *} \\ \text { Koejäsenryhmät }- \text { Groups of treatments }(\mathrm{c})^{* * * *} & \mathrm{~b} \mathrm{x} \mathrm{c}\end{array}$

on ollut rukiilla noin kaksi kertaa parempi kuin kevätviljoilla. Kalin vaikutus on myös rukiilla tehostunut kalkituksen johdosta. Menetelmillä I ja II lasketut typen ja kalin vaikutusluvut poikkeavat selvästi toisistaan. Typpijäsenen alhainen sato pienentää keskimääräisen vaikutuksen mukaan (menetelmä I) laskien typen osuutta. Toisaalta menetelmä II ei anna ravinteiden vaikutuksista tarkasti oikeata kuvaa, sillä koejäsenryhmässä A keskimääräinen kalin vaikutus on negatiivinen, vaikka täyslannoituksella saatu sadonlisäys on parempi kuin NP-lannoituksen vaikutus.

Timotei-apilaheinän sadot on ilmoitettu ilmakuivana heinänä ilman odelmasatoja (taulukko 5). Kaikkien pääravinteiden vaikutus on ollut hyvä. Pelkän typpijäsenen sato on jäänyt pienemmäksi kuin fosfori- ja kalijäsenten sadot. Osaksi tästä johtuen menetelmällä I laskettu typen vaikutus on pienempi kuin parittaisista lannoiteyhdistelmistä (menetelmä II) laskettu typen vaikutus. NP-yhteisvaikutus vaikuttaa myös samansuuntaisesti. Fosforilla saadut sadonlisäykset ovat pienentyneet kalkituksen seurauksena (taulukko 6).

Taulukossa 7 esitetään kaikkien kasvien keskimääräiset sadot rehuyksikköinä hehtaarilta. Ry-sadot on laskettu seuraavia korvauslukuja käyttäen: ohra, ruis ja kevätvehnä 1.0, hernekaura 1.1, heinä 2.5 , ohran ja hernekauran oljet 4.0 sekä rukiin ja vehnän oljet 5.0. Koesatojen suuren lukumäärän (20) takia satunnaisvaihtelun vaikutus on pieni, mikä näkyy testien tuloksista. Esimerkiksi koejäsen- 
Taulukko 4. Eri ravinteiden keskimääräinen vaikutus rukiin jyväsatoihin, $\mathrm{kg} / \mathrm{ha}$ (4 vuotta).

Table 4. Average effect of different nutrients on the grain yields of rye, $\mathrm{kg}$ per ha (4 years).

\begin{tabular}{|c|c|c|c|c|c|c|}
\hline $\begin{array}{l}\text { Ravinne } \\
\text { Nutrient }\end{array}$ & $\begin{array}{l}\text { Menetelmä } \\
\text { Method }\end{array}$ & \multicolumn{4}{|c|}{$\begin{array}{l}\text { Sadonlisäykset eri vuosina } \\
\text { Increases in yield in different years }\end{array}$} & $\begin{array}{l}\text { Keskim. } \\
\text { Average }\end{array}$ \\
\hline \multicolumn{7}{|c|}{ Koejäsenryhmä A - Treatment group $A$} \\
\hline \multirow[t]{2}{*}{$\mathrm{N}$} & I & 163 & 72 & -46 & -29 & 40 \\
\hline & II & 246 & 133 & 87 & 10 & 119 \\
\hline \multirow[t]{2}{*}{$\mathbf{P}$} & I & 138 & 42 & 550 & 479 & 302 \\
\hline & II & 157 & 14 & 577 & 500 & 311 \\
\hline \multirow[t]{2}{*}{ K } & I & 39 & -4 & -164 & 220 & 22 \\
\hline & II & -63 & -37 & -324 & 160 & -66 \\
\hline \multirow[t]{2}{*}{ NPK } & & 340 & 110 & 340 & 670 & 364 \\
\hline & \multicolumn{5}{|c|}{ Koejäsenryhmä B - Treatment group $B$} & \\
\hline \multirow[t]{2}{*}{$\mathbf{N}$} & I & 183 & -73 & 82 & -61 & 33 \\
\hline & II & 263 & -10 & 206 & -90 & 92 \\
\hline \multirow[t]{2}{*}{$\mathbf{P}$} & I & 163 & 37 & 712 & 513 & 356 \\
\hline & II & 84 & -30 & 757 & 530 & 336 \\
\hline \multirow[t]{2}{*}{$\mathrm{K}$} & I & 194 & 76 & 166 & 258 & 174 \\
\hline & II & 193 & 80 & -3 & 270 & 135 \\
\hline NPK & & 540 & 40 & 960 & 710 & 563 \\
\hline
\end{tabular}

1) kevätruis - spring rye

Taulukko 5. Lannoitusten ja kalkituksen vaikutus heinäsatoihin, kg/ha (10 vuotta).

Table 5. The effect of fertilizations and liming on the yields of hay, kg per ha (10 years).

\begin{tabular}{|c|c|c|c|c|}
\hline 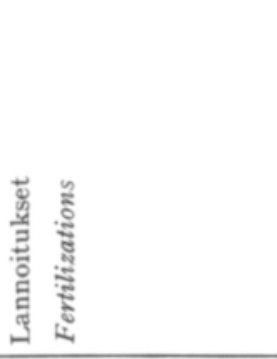 & 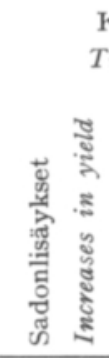 & 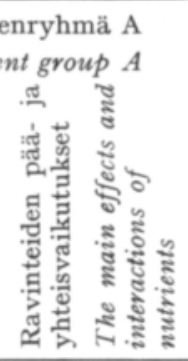 & 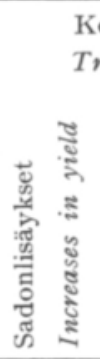 & 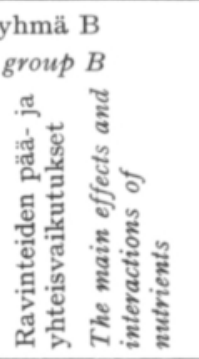 \\
\hline (1) Sato - Yield & $(4925)$ & - & $(5354)$ & - \\
\hline $\mathbf{N}$ & 235 & $328 * * *$ & 104 & $403^{* * *}$ \\
\hline $\mathbf{P}$ & 516 & $472^{* * *}$ & 158 & $392 * * *$ \\
\hline K & 689 & $416 * * *$ & 236 & $391 * * *$ \\
\hline NP & 1022 & $186^{*}$ & 745 & 135 \\
\hline NK & 738 & -43 & 667 & 57 \\
\hline NPK & 1266 & 50 & 1080 & -106 \\
\hline PK & 746 & -180 & 591 & 1 \\
\hline & $s$ & $\begin{array}{l}\text { Vuodet }-\mathrm{Yec} \\
\text { Lannoitukset } \\
\text { Koejäsenryhm }\end{array}$ & $\begin{array}{l}\text { tions (b) } \\
\text { ps of trea }\end{array}$ & $\begin{array}{llll} & \mathrm{a} & \mathrm{x} & \mathrm{b} * \\
\mathrm{a} & \mathrm{x} & \mathrm{c}^{*} \\
\mathrm{c})^{* * *} & \mathrm{~b} & \mathrm{x} & \mathrm{c}\end{array}$ \\
\hline
\end{tabular}


Taulukko 6. Eri ravinteiden keskimääräinen vaikutus heinäsatoihin, $\mathrm{kg} / \mathrm{ha} \mathrm{ja} \mathrm{kg} / \mathrm{ravinne} \mathrm{kg}(10 \mathrm{vuotta})$. Table 6. Average effect of different nutrients on the yields of hay, $\mathrm{kg}$ per ha and $\mathrm{kg}$ per $\mathrm{kg}$ nutrient (10 years).

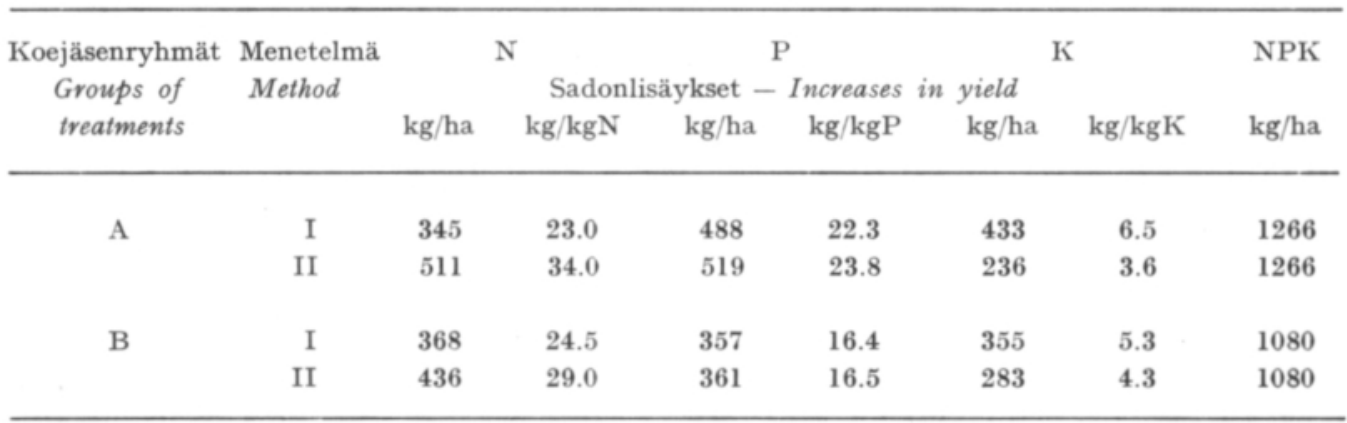

Taulukko 7. Lannoitusten ja kalkituksen keskimääräinen vaikutus kaikilla kasveilla, ry/ha (20 vuotta) Table 7. Average effect of fertilizations and liming on all crops, f.u. per ha (20 years).

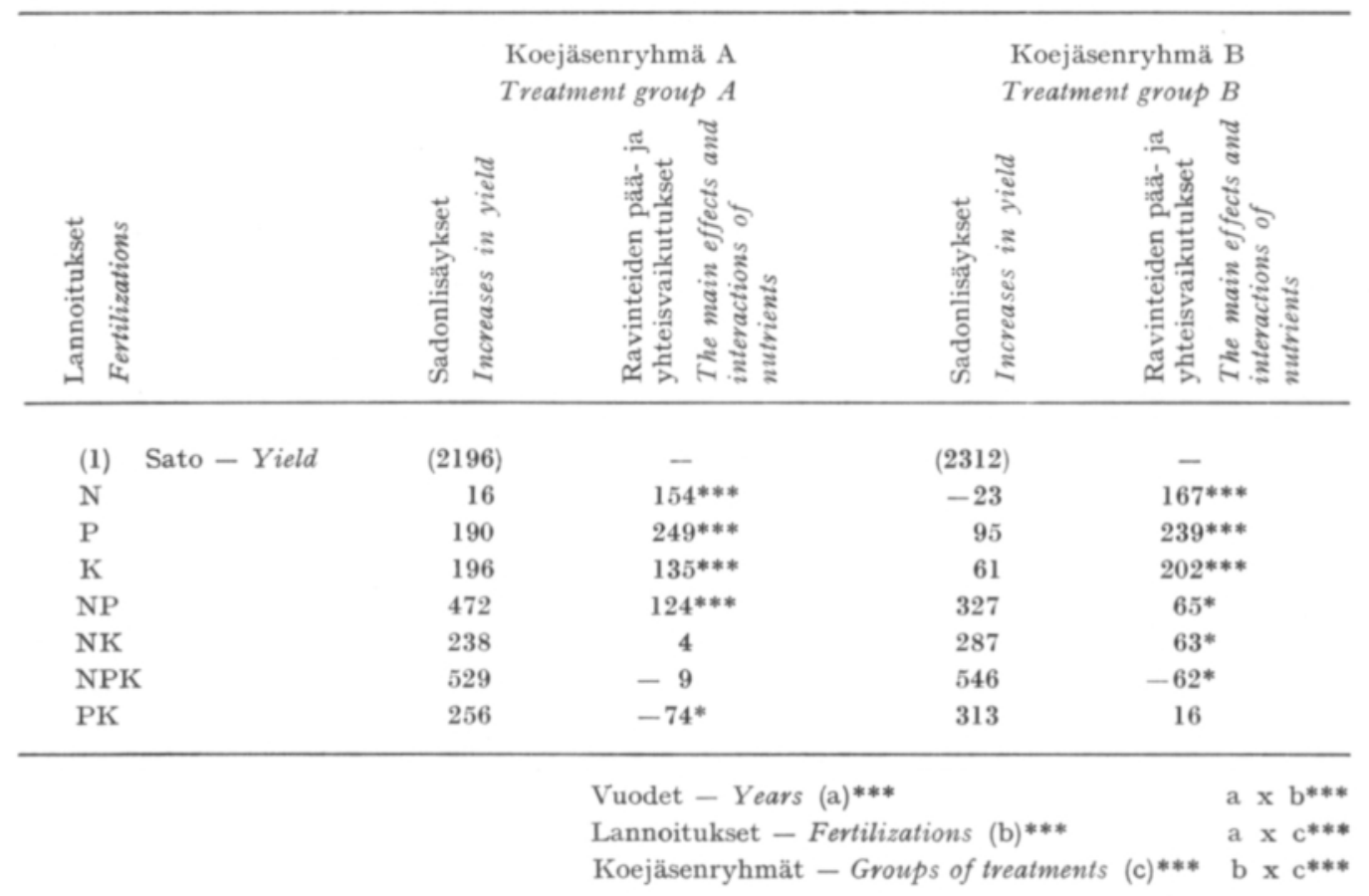

ryhmien ja lannoitusten yhteisvaikutus on erittäin merkitsevä $(\mathrm{P}<0.001)$, minkä mukaisesti kalkitus on aiheuttanut muutoksia lannoiteyhdistelmien tehoon. Monet ravinteiden yhteisvaikutukset ovat merkitseviä. Esimerkiksi NP-yhteisvaikutus koejäsenryhmässä A osoittaa, että typen vaikutus on ollut erittäin merkitsevästi $(\mathrm{P}<0.001)$ parempi fosforilannoituksen "normaalisella» tasolla kuin fosforilannoituksen 0-tasolla. Kalkitus on lisännyt kokeessa kalilannoituksen keskimääräistä vaikutusta (taulukko 8 ). 
Taulukko 8. Eri ravinteiden keskimääräinen vaikutus kaikilla kasveilla, ry/ha ja ry/ravinne kg (20 vuotta)

Table 8. Average effect of different nutrients on all crops, f.u. per ha and f.u. per kg nutrient (20 years).

\begin{tabular}{|c|c|c|c|c|c|c|c|c|}
\hline \multirow{3}{*}{$\begin{array}{c}\text { Koejäsenryhmät } \\
\text { Groups of } \\
\text { treatments }\end{array}$} & \multirow{3}{*}{$\begin{array}{c}\text { Menetelmä } \\
\text { Method }\end{array}$} & \multicolumn{2}{|c|}{$\mathbf{N}$} & \multicolumn{2}{|c|}{$\mathrm{P}$} & \multicolumn{2}{|r|}{$\mathbf{K}$} & \multirow[t]{2}{*}{ NPK } \\
\hline & & & Sadon! & aykset - & Increases & yields & & \\
\hline & & $\begin{array}{c}\text { ry/ha } \\
f . u . \\
\text { per ha }\end{array}$ & $\begin{array}{c}\mathrm{ry} / \mathrm{kgN} \\
f . u . \\
\text { per } \mathrm{kgN}\end{array}$ & $\begin{array}{c}\text { ry/ha } \\
f . u . \\
\text { per ha }\end{array}$ & $\begin{array}{c}\mathrm{ry} / \mathrm{kgP} \\
\text { f.u. } \\
\text { per kgP }\end{array}$ & $\begin{array}{c}\text { ry/ha } \\
\text { f.u. } \\
\text { per ha }\end{array}$ & $\begin{array}{c}\mathrm{ry} / \mathrm{kgK} \\
f . u . \\
\text { per } \mathrm{kgK}\end{array}$ & $\begin{array}{l}\text { ry/ha } \\
\text { f.u. } \\
\text { per ha }\end{array}$ \\
\hline \multirow[t]{2}{*}{ A } & I & 151 & 10.1 & 246 & 11.3 & 132 & 2.0 & 529 \\
\hline & II & 242 & 16.1 & 260 & 11.9 & 27 & 0.4 & 529 \\
\hline \multirow[t]{2}{*}{ B } & I & 147 & 9.8 & 218 & 10.0 & 181 & 2.7 & 546 \\
\hline & II & 178 & 11.9 & 204 & 9.3 & 164 & 2.5 & 546 \\
\hline
\end{tabular}

Taulukko 9. Karjanlantakokeen tulokset, ry/ha (15 vuotta).

Table 9. Results of farmyard manure experiment, f.u. per ha (15 years).

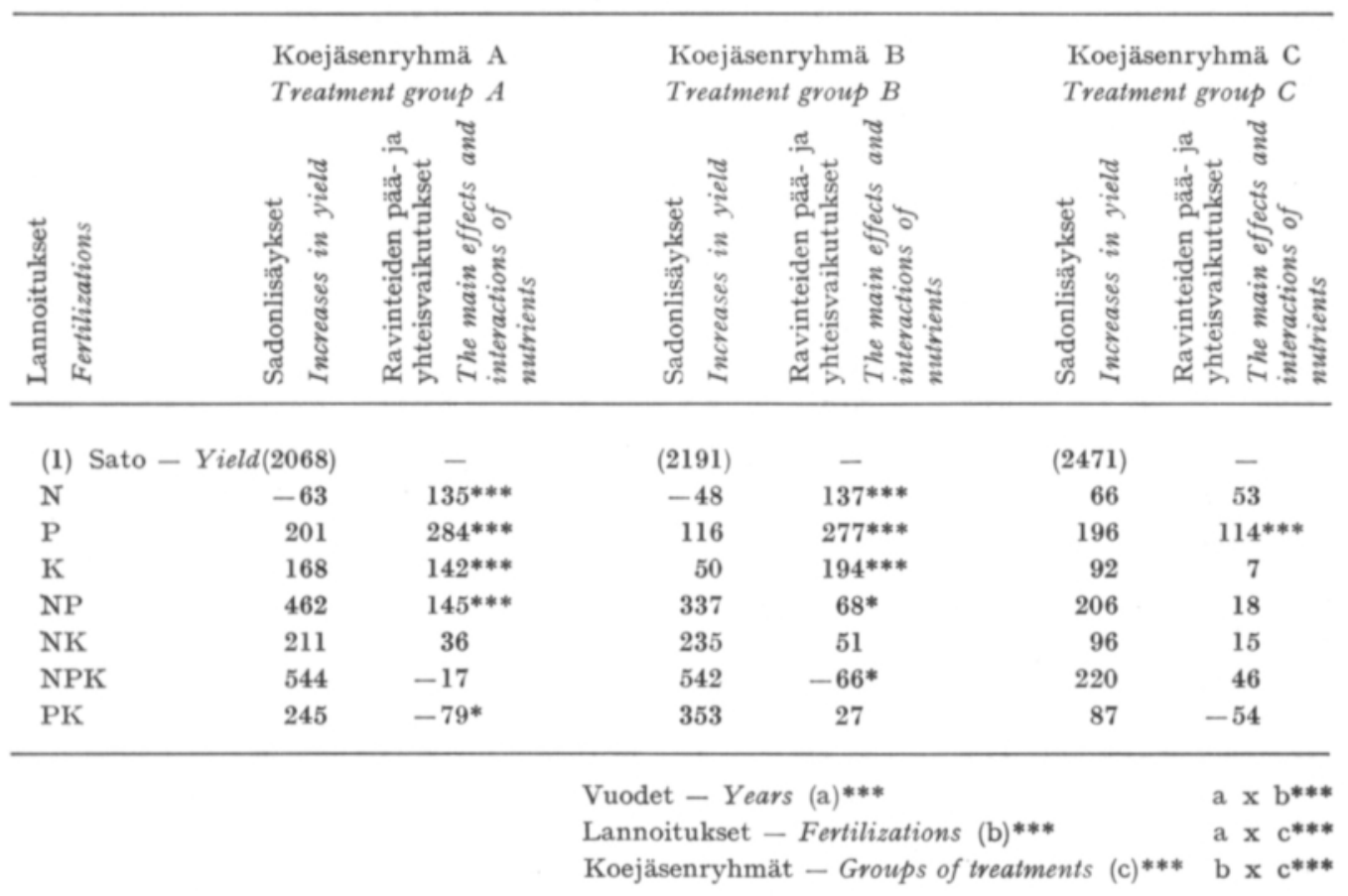

\section{Karjanlantakokeen tulokset}

Karjanlantajäsen on otettu kokeeseen vuonna 1949. Taulukossa 9 esitetään tulokset ry-satoina hehtaarilta. Vastaavalta ajalta on laskettu myös muiden koejäsenryhmien tulokset. Karjanlanta on parantanut yksipuolisen väkilantalannoituk- 
Taulukko 10. Nurmien kasvilajikoostumus (\%) keskimäärin vuosina $1950,-52$ ja -57 .

Table 10. Botanical composition (\%) of leys, average in the years 1950, -52 and -57 .

\begin{tabular}{|c|c|c|c|c|c|c|c|c|c|}
\hline \multirow[b]{2}{*}{ 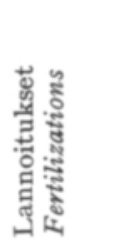 } & \multicolumn{4}{|c|}{ Hyötykasvit - Cultivated plants } & \multicolumn{4}{|c|}{ Rikkakasveista - Weeds } & \multirow[b]{2}{*}{ 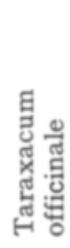 } \\
\hline & 㤩品 & 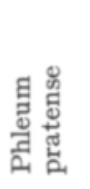 & 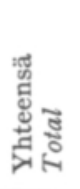 & 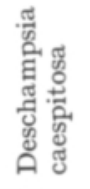 & 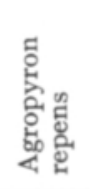 & 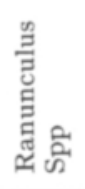 & 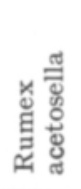 & 兽总总 & \\
\hline \multicolumn{10}{|c|}{ Koejäsenryhmä A - Treatment group $A$} \\
\hline (1) & 43.8 & 20.7 & 64.5 & 13.3 & 7.5 & 0.5 & 2.4 & 4.9 & 3.0 \\
\hline $\mathrm{N}$ & 29.9 & 20.9 & 50.8 & 20.7 & 14.2 & 0.7 & 2.6 & 5.6 & 2.0 \\
\hline P & 45.8 & 20.7 & 66.5 & 14.8 & 7.1 & 0.3 & 1.5 & 3.5 & 3.8 \\
\hline $\mathbf{K}$ & 44.1 & 12.5 & 56.6 & 19.2 & 10.4 & 0.3 & 1.2 & 6.7 & 2.1 \\
\hline NP & 34.4 & 24.5 & 58.9 & 13.7 & 18.0 & 0.3 & 0.6 & 4.6 & 1.9 \\
\hline NK & 33.7 & 20.6 & 54.3 & 15.6 & 17.3 & 0.2 & 1.6 & 6.6 & 1.6 \\
\hline NPK & 39.3 & 24.8 & 64.1 & 7.5 & 16.9 & 0.2 & 0.6 & 4.4 & 2.0 \\
\hline PK & 50.8 & 16.7 & 67.5 & 8.8 & 13.6 & 0.3 & 0.8 & 3.2 & 1.9 \\
\hline $\begin{array}{l}\text { Keskim. } \\
\text { Average }\end{array}$ & 40.2 & 20.2 & 60.4 & 14.2 & 13.1 & 0.4 & 1.4 & 4.9 & 2.3 \\
\hline
\end{tabular}

Koejäsenryhmä B - Treatment group $B$

\begin{tabular}{|c|c|c|c|c|c|c|c|c|c|}
\hline (1) & 56.0 & 18.0 & 74.0 & 4.8 & 9.1 & 0.3 & 1.3 & 3.5 & 2.8 \\
\hline $\mathbf{N}$ & 37.6 & 26.6 & 64.2 & 7.5 & 17.4 & 0.6 & 2.2 & 2.7 & 3.2 \\
\hline P & 53.8 & 19.2 & 73.0 & 5.6 & 8.8 & 0.3 & 1.9 & 3.6 & 2.5 \\
\hline $\mathbf{K}$ & 56.2 & 14.9 & 71.1 & 5.6 & 10.7 & 0.5 & 1.9 & 4.3 & 2.8 \\
\hline NP & 42.3 & 30.5 & 72.8 & 7.9 & 10.1 & 0.6 & 0.6 & 2.2 & 1.6 \\
\hline NK & 48.8 & 21.6 & 70.4 & 4.4 & 14.1 & 0.4 & 0.6 & 4.5 & 3.5 \\
\hline NPK & 43.2 & 27.5 & 70.7 & 2.7 & 14.2 & 0.2 & 0.3 & 4.3 & 3.9 \\
\hline PK & 58.3 & 15.7 & 74.0 & 4.2 & 11.2 & 0.3 & 0.4 & 0.4 & 3.3 \\
\hline $\begin{array}{l}\text { Keskim. } \\
\text { Average }\end{array}$ & 49.5 & 21.8 & 71.3 & 5.3 & 12.0 & 0.4 & 1.2 & 3.2 & 3.0 \\
\hline
\end{tabular}

Koejäsenrymä C - Treatment group $C$

\begin{tabular}{|c|c|c|c|c|c|c|c|c|c|}
\hline (1) & 41.3 & 28.8 & 70.1 & 6.9 & 11.5 & 0.5 & 0.7 & 3.6 & 1.3 \\
\hline $\mathrm{N}$ & 36.8 & 38.5 & 75.3 & 6.2 & 8.8 & 0.2 & 0.6 & 3.2 & 2.8 \\
\hline P & 45.5 & 32.2 & 77.7 & 4.3 & 8.9 & 0.3 & 0.5 & 2.9 & 2.2 \\
\hline K & 43.1 & 34.4 & 77.5 & 7.9 & 5.9 & 0.1 & 0.3 & 3.0 & 2.5 \\
\hline NP & 40.0 & 43.2 & 83.2 & 3.8 & 4.6 & 0.2 & 0.4 & 3.4 & 1.1 \\
\hline NK & 41.5 & 39.0 & 80.7 & 6.5 & 5.8 & 0.1 & 0.3 & 3.4 & 1.7 \\
\hline NPK & 37.0 & 38.6 & 75.6 & 5.5 & 10.1 & 0.3 & 0.2 & 0.3 & 2.5 \\
\hline PK & 52.1 & 25.5 & 77.6 & 6.2 & 7.7 & 0.2 & 0.9 & 3.1 & 1.5 \\
\hline $\begin{array}{l}\text { Keskim. } \\
\text { Average }\end{array}$ & 42.2 & 35.0 & 77.2 & 5.9 & 7.9 & 0.2 & 0.5 & 2.9 & 2.0 \\
\hline
\end{tabular}


sen saaneiden koejäsenten satoja. NPK-lannoitusta käytettäessä karjanlannan vaikutus on jäänyt kuitenkin pieneksi. Fosforin päävaikutus on karjanlantaa käytettäessä erittäin merkitsevä $(\mathrm{P}<0.001)$. Kokeesta ei saada kuitenkaan selvitetyksi sitä, olisiko kalkitus karjanlannan ohella käytettynä aiheuttanut muutoksia ravinteiden vaikutuksiin.

Taulukko 11. Maa-analyysien tulokset vuosina 1951 ja 1966.

Table 11. The results of soil analyses in the years 1951 and 1966.

\begin{tabular}{|c|c|c|c|c|c|c|c|c|c|c|}
\hline \multirow{2}{*}{\multicolumn{2}{|c|}{$\begin{array}{l}\text { Koejäsenryhmät } \\
\text { Groups of } \\
\text { treatments }\end{array}$}} & \multicolumn{8}{|c|}{ Lannoitukset - Fertilizations } & \multirow{2}{*}{$\begin{array}{l}\text { Keskim } \\
\text { Average }\end{array}$} \\
\hline & & (1) & $\mathbf{N}$ & $\mathbf{P}$ & $\mathbf{K}$ & NP & NK & NPK & PK & \\
\hline \multicolumn{11}{|c|}{$\mathrm{pH}$} \\
\hline \multirow[t]{2}{*}{ A } & 1 & 5.53 & 5.48 & 5.45 & 5.53 & 5.55 & 5.58 & 5.55 & 5.48 & 5.52 \\
\hline & 2 & 5.65 & 5.64 & 5.54 & 5.61 & 5.58 & 5.66 & 5.61 & 5.59 & 5.61 \\
\hline \multirow[t]{2}{*}{ B } & 1 & 5.70 & 5.80 & 5.80 & 5.88 & 5.68 & 5.70 & 5.60 & 5.65 & 5.73 \\
\hline & 2 & 5.86 & 5.96 & 5.91 & 6.01 & 5.90 & 5.91 & 5.83 & 5.86 & 5.91 \\
\hline \multirow[t]{2}{*}{ C } & 1 & 5.70 & 5.65 & 5.60 & 5.63 & 5.58 & 5.63 & 5.63 & 5.73 & 5.64 \\
\hline & 2 & 5.55 & 5.56 & 5.54 & 5.60 & 5.59 & 5.69 & 5.59 & 5.60 & 5.59 \\
\hline
\end{tabular}

$\mathrm{K} \mathrm{mg} / \mathrm{l}$ maata $-K \mathrm{mg}$ per litre soil

$\begin{array}{rrrrrrrrrrr}\text { A } & 1 & 58 & 46 & 49 & 96 & 48 & 82 & 66 & 98 & 68 \\ & 2 & 60 & 49 & 48 & 150 & 55 & 129 & 136 & 148 & 97 \\ & & & & & & & & & & \\ \text { B } & 1 & 41 & 62 & 48 & 90 & 35 & 63 & 55 & 56 & 56 \\ & 2 & 59 & 61 & 69 & 161 & 56 & 146 & 133 & 146 & 104 \\ & & & & & & & & & & \\ \text { C } & 1 & 105 & 79 & 79 & 93 & 93 & 102 & 134 & 172 & 107 \\ & 2 & 146 & 125 & 144 & 226 & 159 & 231 & 224 & 230 & 186\end{array}$

$\mathrm{P} \mathrm{mg} / \mathrm{l}$ maata $-P$ mg per litre soil

$\begin{array}{rrrrrrrrrrr}\mathrm{A} & 1 & 3.3 & 3.2 & 4.7 & 4.1 & 4.7 & 3.4 & 4.3 & 4.1 & 4.0 \\ & 2 & 3.8 & 3.6 & 5.5 & 4.2 & 5.2 & 3.8 & 5.8 & 6.6 & 4.8 \\ & & & & & & & & & & \\ \mathrm{~B} & 1 & 3.4 & 7.0 & 8.0 & 6.7 & 4.1 & 3.0 & 3.7 & 4.1 & 5.0 \\ & 2 & 6.4 & 5.0 & 7.9 & 6.6 & 5.6 & 4.2 & 6.5 & 6.9 & 6.1 \\ & & & & & & & & & & \\ \mathrm{C} & 1 & 4.6 & 5.4 & 4.6 & 5.8 & 4.3 & 4.4 & 5.8 & 5.4 & 5.0 \\ & 2 & 6.0 & 6.6 & 8.8 & 9.2 & 7.4 & 6.5 & 9.3 & 10.0 & 8.0\end{array}$

$\mathrm{Ca} \mathrm{mg} / \mathrm{l}$ mata $-\mathrm{Ca}$ mg per litre soil

$\begin{array}{llllrrrrrrr}\text { A } & 2 & 550 & 525 & 575 & 488 & 669 & 500 & 580 & 544 & 554 \\ \text { B } & 2 & 894 & 969 & 1025 & 931 & 1063 & 981 & 919 & 869 & 956 \\ \text { C } & 2 & 738 & 688 & 756 & 700 & 756 & 688 & 750 & 756 & 729\end{array}$

$1=$ Vuonna 1951 - In the year 1951

$2=$ Vuonna $1966-$ In the year 1966 


\section{Lannoitusten ja kalkituksen vaikutus nurmien kasvilajikoostumukseen}

Kokeessa olleista nurmista on tehty botaanisia määrityksiä vuosina 1950 , 1952 ja 1957. Taulukosta 10 nähdään yhden ensimmäisen vuoden ja kahden kolmannen vuoden nurmen keskimääräinen kasvilajikoostumus, mikä kuvastaa timotein ja apilan sekä yleisimpinä esiintyneiden rikkakasvien suhtautumista lannoitukseen ja kalkitukseen. Apila on selvästi hyötynyt kalkituksesta. Apilaprosentit ovat suurimmat PK-lannoituksen saaneilla koejäsenillä. Myös todelliset apilasadot ovat PK-lannoituksella suurempia kuin esimerkiksi täyslannoituksella, mikä johtunee pääasiallisesti siitä, että heinäkasvit pystyvät käyttämään typpilannoituksen tehokkaammin kuin apila. Karjanlanta on edistänyt timotein kasvua. Myös NPlannoitus on lisännyt timotein osuutta.

Rikkakasveista nurmilauhan osuus on pienentynyt kalkituksen ja monipuolisen lannoituksen seurauksena. Typpilannoitus on edistänyt juolavehnän kasvua. Keskimäärin rikkakasvien osuudet ovat pienimmät karjanlantaa käytettäessä.

\section{Koetulosten tarkastelua}

Lannoitteilla saadut sadonlisäykset riippuvat $\mathrm{mm}$. maalajista, viljelykasvista, kasvupaikan maantieteellisestä sijainnista sekä käytetyistä lannoitemääristä. Selostettavassa kokeessa saadut tulokset eivät täten ole suoraan verrattavissa muiden lannoituskokeiden tuloksiin. Typellä saadut kevätviljojen jyväsadonlisäykset ovat suuruusluokaltaan samoja kuin paikalliskokeissa (TENNBERG 1955). Fosforin ja kalin vaikutus kevätviljojen jyväsatoihin vastaa hyvin Etelä-Suomen (Turun ja Porin, Uudenmaan ja Hämeen läänit) paikalliskokeiden tuloksia hietamailta. Kiinteillä koekentillä on SALOSEN ja TAINION (1957) mukaan $54.9 \mathrm{~kg} \mathrm{P}_{2} \mathrm{O}_{5}$ antanut sadonlisäystä hieta- ja hietamoreenimailla 324 ry/ha, mikä on vähän suurempi kuin esitetyssä kokeessa. Kalin vaikutus on hietamailla ollut SALOSEN ja TAINION (1961) mukaan parempi kuin suoritetussa kokeessa. Saadut sadonlisäysluvut vastaavat parhaiten Etelä-Suomen hietamailta saatuja tuloksia.

Maantutkimuslaitos on tehnyt koealueesta maa-analyysejä vuosina 1951 ja 1966. Vuoden 1951 tulokset on muunnettu nykyisen ilmoitustavan mukaisiksi KURJEN ym. (1965) esittämällä tavalla. Kalkituksen vaikutus maan pH-lukuun ja vaihtuvan kalsiumin määriin on selvästi todettavissa (taulukko 11). Karjanlannoitus on lisännyt liukoista fosforia ja erityisesti liukoista kalia. Tästä huolimatta satotaso ei ole ollut korkeampi kuin NPK-lannoituksella ja kalkituksella saatu (taulukko 9). Kalkituksen seurakusena fosforiluvut ovat nousseet, millä on ilmeisesti ollut vaikutusta fosforilannoituksella saatujen heinäsadonlisäysten pienenemiseen. Rukiilla ei ole mainitunlaista sadonlisäysten pienenemistä todettavissa, mikä johtunee sen suuresta fosforintarpeesta (vrt. TENNBERG 1955). LAKANEN ja VuORINEN (1963) ovat todenneet kalkituksen pienentävän moreenimailla liukoisen kalin määrää. Vuonna 1951 suoritetun viljavuustutkimuksen mukaan liukenevaa kalia oli kalkituissa lannoitusjäsenissä vähemmän kuin kalkitsemattomissa. Vuonna 1966 kaliluvut olivat selvästi edellisiä suuremmat kalilannoituksen saaneilla koejäsenillä eikä kalkituksen vaikutusta kalimääriin ole todettavissa. Kalin vaikutus on ollut 
kuitenkin jatkuvasti parempi kalkituksen saaneilla koejäsenillä kuin kalkitsemattomilla, joskin vuotuisvaihtelut ovat suuria. Vuosina $1944-51$ oli kalilannoituksen osuus NPK-lannoituksen vaikutuksesta ilman kalkitusta -3 ry/ha ja kalkituksen yhteydessä $263 \mathrm{ry} / \mathrm{ha}$ vuodessa sekä vuosina $1952-65$ vastaavasti 47 ja $148 \mathrm{ry} / \mathrm{ha}$.

\section{Ti ivistelmä}

Suoviljelysyhdistyksen Karjalan koeasemalla Tohmajärvellä on tutkittu vaaramoreenin lannoitus- ja kalkitustarvetta pitkäaikaisella kenttäkokeella. Tällöin on todettu, että satotaso sekä lannoituksella ja kalkituksella saadut sadonlisäykset vaihtelevat vuosittain voimakkaasti samallakin kasvilajilla. Väkilannoitteilla saadut sadonlisäykset vastaavat parhaiten Etelä-Suomen hietamailta saatuja sadonlisäyksiä. Lannoiteyhdistelmällä on ollut vaikutusta eri ravinteilla saatujen sadonlisäysten suuruuteen. Kalkitus on lisännyt satoja ja on aiheuttanut muutoksia ravinteiden vaikutuksiin. Kalkitus on lisännyt liukoisen fosforin määriä maassa ja sen johdosta fosforilannoituksella saadut nurmikasvien sadonlisäykset ovat pienentyneet. Kalilannoituksen vaikutus on kalkituksen seurauksena tehostunut. Karjanlanta on lisännyt muokkauskerroksen liukoisen fosforin ja kalin määriä. Karjanlantalannoitus on suurentunut yksipuolisen väkilantalannoituksen saaneiden koejäsenten satoja, mutta NPK-lannoitusta käytettäessä sen vaikutus on jäänyt pieneksi.

Kalkitus ja PK-lannoitus ovat lisänneet apilan osuutta nurmissa. Nurmilauhan määrä on pienentynyt monipuolisen lannoituksen ja kalkituksen seurauksena. Typpilannoitus näyttää lisänneen juolavehnän osuutta nurmissa.

KIRJALLISUUTTA:

BaILey, N. 1964. Statistical methods in biology. 200 p. London.

Bonnier, G. \& Tedin, O. 1957. Biologisk variations analys. 185 p. Stockholm.

Krvinen, E. 1941. Tutkimuksia vaara-alueiden moreenimaiden ominaisuuksista. Agrogeol. julk. 51: $10-33$.

Kurki, M., Lakanen, E., Mäkitie, O., Sillanpāā, M. \& Vuorinen, J. 1965. Viljavuusanalyysien tulosten ilmoitustapa ja tulkinta. Summary: Interpretation of soil testing results. Ann. Agric. Fenn. 4: 145-153.

LAKANEN, E. \& VUORINEN, J. 1963. On the effect of liming on the solubility of nutrients in various Finnish soils. Selostus: Kalkin vaikutuksesta ravinteiden liukoisuuteen. Ibid. 2: 91-102.

SALонегмо, L. 1951. Vaaramoreenimaan kalkitus- ja lannoitustarpeesta. Koetoim. ja Käyt. 8-9: 3.

" 1958. Vaaramaan maanparannus- ja lannoituskokeen tuloksia. Suovilj. yhd. vuosik. 63: 19-23.

SAlonen, M. \& TAINIO, A. 1957. Fosforilannoitusta koskevia tutkimuksia. Valt. Maatal. koetoim. julk. 164: $1-104$.

- 1961. Kalilannoitusta koskevia tutkimuksia. Ibid. 185: 1-60.

TEnNBerg, F. 1939. Synpunkter på tolkning av resultaten från gödslingsförsök med indirekt plan Nord. Jordbr. Forskn. 1-2.

- 1955. Väkilannoitteissa annettujen ravinteiden satoa lisăävästă vaikutuksesta Suomessa. Väkilannoitteet maataloutemme kohottajina. Pellervo-Seura. Erip. Helsinki. 


\title{
RESULTS FROM A FERTILIZING AND LIMING TEST ON HILL MORAINE
}

\author{
HEIKKI LUOSTARINEN
}

\author{
Society of Peat Cultivation, Karelia Experimental Station, Tohmajärvi
}

At the Karelia Experimental Station (at Tohmajärvi) of the Society of Peat Cultivation the fertilizing and liming requirements of hill moraine (cf. Krvinen 1941) have been studied in a long-term field test established in 1944. The effects of nitrogen, phosphorus and potassium given in artificial fertilizers on the crop yield were observed both without liming and when liming and farmyard manure were applied. The following test members were included:

(A) Test member group without lime and without farmyard manure. Fertilizers: (1), N, P, K, $\mathrm{NP}, \mathrm{NK}, \mathrm{NPK}$, and $\mathrm{PK} . \mathrm{N}=15 \mathrm{~kg} \mathrm{~N}$ per hectare as calcium nitrate, $\mathrm{P}=21.9 \mathrm{~kg} \mathrm{P}$ per hectare as superphosphate, and $\mathrm{K}=66.4 \mathrm{~kg} \mathrm{~K}$ per hectare as potassium salt, annually.

(B) Test member group in which ground limestone was applied at $2000 \mathrm{~kg}$ per hectare as top dressing on grass ley in the year the test was established (1944) and the same amount of limestone was given once again in 1951. Fertilizers as in test member group (A).

(C) Test member group included in the tests in 1949. Farmyard manure fertilizing at $40.000 \mathrm{~kg}$ per hectare, repeated in 1962. Fertilizers as in test member group (A).

The contributions of the different nutrients towards the crop yield increment achieved with NPK fertilizing were calculated by distributing the combined NPK effect evenly among the different main effects (Method I). The effects of the nutrients were also calculated from binary fertilizer combinations in the manner presented by TENNBERG (1939) (Method II).

The spring cereals were treated as one group as the test years were too few to allow a separate study of the individual species. Barley and spring wheat occurred twice in the test and mixed peas and oats once. The test results are presented in Tables 1 and 2. Winter rye was present in the tests three times and spring rye once in 1961. The effect of phosphorus was favourable with rye (Tables 3 and 4 ).

Timothy-clover grass was included in the test in the years $1944-1946,1950-1952$ and $1955-$ 1958. The crop yields are stated as air-dry hay without aftermath yields, in Tables 5 and 6 . Tables 7 and 8 contain the crop yield results of all plants.

It was noted that the crop yield level and the increases in crop yield obtained with fertilizing as well as liming varied greatly in different years even with one and the same plant species. A combination of fertilizers affected the crop yield increments produced by different nutrients. Liming increased the crop yields and caused changes in the effects of the nutrients. Liming increased the amounts of soluble phosphorus in the soil (Table 11), and the increments in crop yield of grassland plants obtained with phosphorus fertilizing consequently decreased. The effect of potassium fertilizing was enhanced as result of liming. Farmyard manure increased the soluble potassium and phosphorus quantities. Farmyard manure dressing increased the crop yields of the treatments given onesided fertilizer additions, while its effect remained low in association with NPK fertilization (Table 9).

Liming and PK fertilizing increased the percentage of clover in grass leys (Table 10). That of tufted hair grass was reduced as a result of diversified fertilizing and of liming. Nitrogen fertilization seems to have increased the porportion of couchgrass in the grass leys. 